\title{
Improvement of small seed for big nutritional feed
}

\author{
P. B. Kavi Kishor ${ }^{1}$ (I) S. Anil Kumar ${ }^{1,2}$. Jalaja Naravula ${ }^{1}$ P. Hima Kumari ${ }^{2}$. \\ Divya Kummari ${ }^{3}$. Rajasheker Guddimalli ${ }^{3}$ Sujatha Edupuganti ${ }^{4}$. \\ Appa Rao Karumanchi ${ }^{5}$ - Perumal Venkatachalam ${ }^{6}$ Prashanth Suravajhala ${ }^{2,7}$. \\ Rathnagiri Polavarapu ${ }^{8}$
}

Received: 3 April 2021/Revised: 4 August 2021/Accepted: 11 September 2021/Published online: 22 September 2021

(c) Prof. H.S. Srivastava Foundation for Science and Society 2021

\begin{abstract}
Exploding global population, rapid urbanization, salinization of soils, decreasing arable land availability, groundwater resources, and dynamic climatic conditions pose impending damage to our food security by reducing the grain quality and quantity. This issue is further compounded in arid and semi-arid regions due to the shortage of irrigation water and erratic rainfalls. Millets are gluten (a family of proteins)-free and cultivated all over the globe for human consumption, fuel, feed, and fodder. They provide nutritional security for the under- and malnourished. With the deployment of strategies like foliar spray, traditional/marker-assisted breeding, identification of candidate genes for the translocation of important minerals, and genome-editing technologies, it is now tenable to biofortify important millets. Since the bioavailability of iron and zinc has been proven in human trials, the challenge is to make such grains accessible. This review encompasses nutri-
\end{abstract}

Dedicated to Late Dr. A. Maruthi Rao who initiated the work on millets in Kavi Kishor's lab.

The authors P. B. Kavi Kishor, S. Anil Kumar, Jalaja Naravula and P. Hima Kumari contributed equally to this work.

\footnotetext{
P. B. Kavi Kishor

pbkavi@yahoo.com

Prashanth Suravajhala prash@bioclues.org

1 Department of Biotechnology, Vignan's Foundation for Science, Technology and Research, Vadlamudi, Guntur, Andhra Pradesh 522 213, India

2 Bioclues.Org, Hyderabad, India

3 Department of Genetics, Osmania University, Hyderabad, Telangana 500 007, India
}

tional benefits, progress made, challenges being encountered, and prospects of enriching millet crops with essential minerals.

Keywords Biofortification - Malnourishment - Millets · Micronutrient deficiency $\cdot$ Translocation of minerals

\section{Introduction}

Global food and nutritional security are under threat with an ever-increasing population, changing climatic conditions, and dwindling natural resources. Plants are exposed frequently to both biotic and abiotic stresses due to their sedentary nature. Both these devastating stresses drastically reduce the biomass and final yields. There are 50,000 edible crops (Cheng et al. 2017), but food production and consumption are mostly dominated by rice, wheat, and maize, thus limiting our ability to deal with adverse conditions and nutritional security at the global level. Millets, often called "famine reserves," are endowed with climateresilience and acclimatization to a broad range of

4 Department of Botany, Osmania University, Hyderabad, Telangana 500 007, India

5 Department of Biotechnology, Acharya Nagarjuna University, Guntur, Andhra Pradesh 522 508, India

6 Department of Biotechnology, Periyar University, Salem, Tamil Nadu 636 011, India

7 Amrita School of Biotechnology, Amrita University, Amritapuri, 690 525, Clappana, Kerala, India

8 Genomix CARL, Rayalapuram Road, Pulivendula, Andhra Pradesh 516 390, India 
ecological conditions, besides less irrigational requirements, optimal growth, and productivity under arid and semi-arid zones. Among many, pearl millet (Varshney et al. 2017), foxtail millet (Bennetzen et al. 2012; Bhat et al. 2018), finger millet (Hittalmani et al. 2017; Hatakeyama et al. 2018), proso millet (Zou et al. 2019), and teff have been sequenced (Cannarozzi et al. 2014).

People in the Asian continent are deficient in micronutrients like $\mathrm{Fe}^{2+}, \mathrm{Zn}^{2+}, \mathrm{Ca}^{2+}$, as well as vitamin A. Millets, are a good source of carbohydrates, proteins, fats, fibers, essential amino acids, and minerals such as $\mathrm{Ca}^{2+}, \mathrm{K}^{+}$, $\mathrm{Fe}^{2+}, \mathrm{Zn}^{2+}$, selenium (Se) (Saleh et al. 2013). Some millets accumulate Se (Table 1) which is an essential trace mineral, known to be a constituent in the biosynthesis of a number of selenoproteins and has been considered as an important antioxidant molecule in human health. Selenocysteine has been recognized as the 21st amino acid and performs several enzymatic functions in the human body. Se assists in modulating intracellular redox state via selenium-dependent glutathione peroxidases, hence prevent the risk of cancer and give protection against peroxynitrite (Allan et al. 1999). Foxtail millet accumulates $100.3 \mu \mathrm{g}$ of Se per $\mathrm{Kg}$ seed weight in many Chinese accessions compared to other millets (Table 1). They form staple food, furnish most of the calories and protein in arid and semiarid tropics, thus providing nutritional security in areas prone to drought and heat stresses. Millets display stress adaptations viz., flowering adjusted to rainfall, increased root length during the drought, accumulation of osmolytes, enhanced antioxidants in little millet (Ajithkumar and Panneerselvam 2014), and low Pi conditions in foxtail millet (Roch et al. 2020). Since millets can provide succor to the subsistence farmers, it is important to surpass the current yield limits, biotic and abiotic stress tolerance too. This review focuses on the nutritional aspects, biofortification, bioavailability, antinutrients, uptake and translocation of minerals, and their role in the accumulation in millet crops.

\section{Millets: productivity, nutrition and medicinal values}

Millets rank sixth among cereal grains and are consumed by one-third of the global population. Asia and Africa constitute $97.6 \%$ of global production, Africa is the leading producer of millets (Habiyaremye et al. 2017), followed by Asia, Europe, the Americas, and Oceania. The global millet production is about 28.37 million tons from 31.65 million hectares (FAOSTAT 2019). India ranks first in the production of millets with 10.23 million tons, followed by Niger, China, Nigeria, Mali, and Sudan with 3.27, 2.3, 2.0, 1.87 , and 1.13 million tons respectively (FAOSTAT 2019).
In India, Assam and Bihar consume the highest amounts of small millets $(18.82 \mathrm{~kg} / \mathrm{hsh} / \mathrm{m}$, and $18.69 \mathrm{~kg} / \mathrm{hsh} / \mathrm{m}$ respectively). Madhya Pradesh has nearly $32.4 \%$ of the small millet grown area, followed by Chhattisgarh (19.5\%), Uttarakhand $(8 \%)$, Maharashtra $(7.8 \%)$, and Gujarat (5.3\%). But productivity is high in Uttarakhand $(1174 \mathrm{~kg} /$ ha), followed by Tamil Nadu (1067 kg/ha) and Gujarat (1056 kg/ha) (Anbukkani et al. 2017). Several millets have high fiber content and can become good components in the diets of patients suffering from obesity, constipation, and gallstones. Millets are rich in a unique type of resistant starch (RS) that has been recognized as a functional fiber that maintains a low glycemic index. There are four types of RS; physically inaccessible starch (type RS1), native granular starch (RS2), retrograded starch (RS3), chemically and thermally modified starch (RS4). In digestive physiology, functional fibre plays an important role. When RS is fermented in the stomach, the metabolic products generated help in the proper functioning of the bowl. RS is similar to soluble, fermentable fiber, and assists in feeding the friendly bacteria in the human gut with an enhanced production of short-chain fatty acid like butyrate. Butyrate plays a key role in gastrointestinal health; helps prevent and treat colon cancer. RS helps with weight loss and beneficial heart health, lowers blood pressure, manages blood sugar levels, insulin sensitivity, and digestive health (Mikulikova et al. 2005). Such information helps in formulating functional food products which can cater to the needs of diverse target groups including marginal farmers. In this review, we considered grain millets, but not Panicum maximum (Guinea grass) and Paspalum notatum (Bahia grass) since they are used mostly for growing lawns or fodder.

(a) Cenchrus americanus [(L.) R. Br.] (formerly known as Pennisetum glaucum [(L.) R. Br.] (Pearl millet) Pearl millet is an allogamic, diploid species with $2 \mathrm{n}=2 \mathrm{x}=14$ chromosomes (Table 2), and provides food security to the poor people of Asia and Africa. Nearly, 31 million hectares of land are being utilized for growing pearl millet and 90 million people depend upon it for food and income. It occupies 50\% of the market share of global millet production. Its production in India is approximately 9 million tons, from a cultivated area of $\sim 8.5$ million hectares during the years 2009-2010 to 2013-2014 (Agricultural Statistics, GOI 2014). India is the largest producer with a total production of 9.1 million metric tons from 7.4 million ha. It displays antiallergic properties and hence can become a part of daily dietary habits for infants, lactating mothers, and convalescents. It has a $600 \%$ higher iron content than rice (Passi and Jain 2014), and is a good source 
Table 1 Minerals, vitamins and amino acids present in diverse millets

\begin{tabular}{|c|c|c|c|}
\hline Millet & Minerals (mg/100 $\mathrm{g}$ of seed) & $\begin{array}{l}\text { Vitamins (mg/100 g seed) (unless otherwise } \\
\text { mentioned) }\end{array}$ & References \\
\hline $\begin{array}{l}\text { Pearl } \\
\text { millet }\end{array}$ & $\begin{array}{l}\mathrm{Zn}(3.1), \mathrm{Fe}(70-180), \mathrm{Ca}(10-80), \\
\mathrm{Cu}(0.54), \mathrm{Se}(5.4 \text { micro grams/ } \\
100 \text { g seed weight), K (440-442) }\end{array}$ & $\begin{array}{l}\text { Folic acid, thiamine }(0.3) \text {, riboflavin }(1.48) \text {, niacin } \\
(1.11) \text {, pantothenic acid }(0.5) \text {, biotin }(0.64)\end{array}$ & $\begin{array}{l}\text { Passi and Jain (2014), Malik (2015), Rac } \\
\text { et al. (2017) and Kumar et al. (2018) }\end{array}$ \\
\hline $\begin{array}{l}\text { Finger } \\
\text { millet }\end{array}$ & $\begin{array}{l}\mathrm{Zn}(36.6), \mathrm{Fe}(3.6), \mathrm{Ca}(376-515), \\
\mathrm{Cu}(0.67), \mathrm{Se}(0.5 \mathrm{mg} \text { in the } \\
\text { variety Pwana), K (408-570) }\end{array}$ & $\begin{array}{l}\text { Thiamine }(0.4) \text {, riboflavin }(0.6) \text {, niacin }(0.8) \text {, } \\
\text { pantothenic acid }(0.29) \text {, biotin }(0.88)\end{array}$ & $\begin{array}{l}\text { Fernandez et al. (2003) and Saleh et al. } \\
\text { (2013) }\end{array}$ \\
\hline $\begin{array}{l}\text { Foxtail } \\
\text { millet }\end{array}$ & $\begin{array}{l}\mathrm{Zn}(60.6), \mathrm{Fe}(2.80), \mathrm{Ca}(31), \mathrm{Cu} \\
\quad(1.4), \mathrm{Se}(100.3 \mu \mathrm{g} / \mathrm{Kg}) \text { in } \\
\text { Chinese accessions, K }(250-400)\end{array}$ & $\begin{array}{l}\text { Vitamin D, Thiamine }(0.6) \text {, riboflavin }(1.65) \text {, } \\
\text { niacin }(0.55) \text {, lysine }(2.3-2.9)\end{array}$ & $\begin{array}{l}\text { Puranik et al. (2017), Rao et al. (2017) } \\
\text { and Kumar et al. (2018) }\end{array}$ \\
\hline $\begin{array}{l}\text { Proso } \\
\text { millet }\end{array}$ & $\begin{array}{l}\mathrm{Zn}(3.7), \mathrm{Fe}(0.8), \mathrm{Ca}(14), \mathrm{Cu} \\
\quad(1.6), \mathrm{Se}(2.70 \mu \mathrm{g}), \mathrm{K}(250-320)\end{array}$ & $\begin{array}{l}\text { Thiamine (0.41), riboflavin (0.28), niacin ( } 4.54) \text {, } \\
\text { folic acid } \\
\text { Essential amino acids like methionine and } \\
\text { cysteine, and lecithin (supports neural health) }\end{array}$ & $\begin{array}{l}\text { Chandel et al. (2014), Shankaramurthy } \\
\text { and Somannavar (2019) and Das et al } \\
\text { (2019) }\end{array}$ \\
\hline $\begin{array}{l}\text { Little } \\
\text { millet }\end{array}$ & $\begin{array}{l}\mathrm{Zn}(3.7), \mathrm{Fe}(9.3), \mathrm{Ca}(350), \mathrm{Cu} \\
\quad(0.34), \mathrm{K}(129-370)\end{array}$ & $\begin{array}{l}\text { Thiamine }(0.26) \text {, riboflavin }(0.05) \text {, niacin }(1.29) \text {, } \\
\text { pantothenic acid }(0.6) \text {, biotin }(6.03) \text {, rich in } \\
\text { methionine, valine, lysine }\end{array}$ & $\begin{array}{l}\text { Chandel et al. (2014), Mbithi-Mwikya } \\
\text { et al. (2000) and Himanshu et al. } \\
\text { (2018) }\end{array}$ \\
\hline $\begin{array}{l}\text { Kodo } \\
\text { millet }\end{array}$ & $\begin{array}{l}\mathrm{Zn}(32.7), \mathrm{Fe}(0.5), \mathrm{Ca}(27), \mathrm{Cu} \\
\quad(0.26), \mathrm{K}(144-170)\end{array}$ & $\begin{array}{l}\text { Thiamine }(0.15) \text {, riboflavin }(2) \text {, niacin }(0.09) \text {, } \\
\text { pantothenic acid }(0.63) \text {, biotin }(1.49)\end{array}$ & $\begin{array}{l}\text { Chandel et al. (2014), Kulkarni and Naik } \\
\text { (2000), Rao et al. (2017), Kumar et al } \\
\text { (2018) and Himanshu et al. (2018) }\end{array}$ \\
\hline $\begin{array}{l}\text { Barnyard } \\
\text { millet }\end{array}$ & $\begin{array}{l}\mathrm{Zn}(57.45), \mathrm{Fe}(6.91), \mathrm{Ca}(11) \\
\mathrm{Cu}(0.6)\end{array}$ & Thiamine $(0.33)$, riboflavin $(4.2)$, niacin $(0.1)$ & $\begin{array}{l}\text { Chandel et al. (2014), Rao et al. (2017) } \\
\text { and Kumar et al. (2018) }\end{array}$ \\
\hline $\begin{array}{l}\text { Teff } \\
\text { millet }\end{array}$ & $\begin{array}{l}\mathrm{Ca}(180), \mathrm{Fe}(7.63), \mathrm{Mg}(184), \mathrm{P} \\
\quad(429), \mathrm{K}(427), \mathrm{Na}(12), \mathrm{Zn}(3.63)\end{array}$ & $\begin{array}{l}\text { Niacin }(3.363) \text {, vitamin B6 }(0.482) \text {, thiamine } \\
(0.39) \text {, riboflavin }(0.27) \text {, vitamin } \mathrm{K} \\
\text { (phylloquinone) }(1.9 \mu \mathrm{g}) \text {, vitamin } \mathrm{A}(9 \mathrm{IU}) \text {, and } \\
\alpha \text {-tocopherol }(0.08)\end{array}$ & $\begin{array}{l}\text { Gebru et al. (2020) } \\
\text { USDA Food Composition Databases } \\
\text { (2017) }\end{array}$ \\
\hline $\begin{array}{l}\text { Fonio } \\
\text { millet }\end{array}$ & $\begin{array}{l}\mathrm{Mg}(2.53), \mathrm{Mn}(0.03), \mathrm{Zn}(0.45), \mathrm{Fe} \\
\quad(0.57), \mathrm{Cu}(0.05), \mathrm{Na}(4.70), \mathrm{Ca} \\
(19.70), \mathrm{K}(26.53), \mathrm{P}(13.42)\end{array}$ & Thiamin (1.50), riboflavin (0.22), niacin (1.15) & $\begin{array}{l}\text { Sanusi et al. (2019) } \\
\text { Barikmo et al. (2007) } \\
\text { Zhu (2020) }\end{array}$ \\
\hline
\end{tabular}

of antioxidants. Nutrients of pearl millet play a role in the prevention of diabetes, cancer, cardiovascular and neurodegenerative diseases. Thus, the potential exists for harnessing the positive attributes of pearl millet that help in nutritional security.

(b) Eleusine coracana (Finger millet)

Finger millet or African finger millet or Coracan or Koracan or Ragi is an important cereal crop of temperate and semi-arid climates. It is an allotetraploid $(2 \mathrm{n}=4 \mathrm{X}=36)$ crop (Table 2$)$ and is commonly called finger millet due to finger-like branching on the panicle. Finger millet is the 6th most important cereal crop and its global production is about 4.5 million metric tons. India ranks first in production with 1.2 million metric tons after Africa with 2.5 million metric tons (Kumar et al. 2016). It is an under-utilized crop for many rural areas of poor nations besides being accounted for $85 \%$ of millets produced in India (Sakamma et al. 2018). Out of 34,160 finger millet genotypes, India has 22,583
(Ramakrishnan et al. 2015). Finger millet protects pregnant women and lactating mothers from micronutrient deficiencies, anti-diabetic, antioxidative (Kumar et al. 2016), and wound healing properties (Manisseri and Gudipati 2012).

(c) Setaria italica (foxtail millet)

Setariaitalica or Panicum italicum (Foxtail millet or Italian millet or German millet or Hungarian millet or Green foxtail, or Foxtail bristle-grass or Giant setaria or Dwarf setaria) has originated in China and is an important millet in China and India. Taxonomically, the genus Setaria comprises two subspecies namely, S. italica and S. viridis. Based on phenotypic features, three races viz., Moharia, Maxima, and Indica have been identified (Rao et al. 1987). It is a self-pollinating crop with chromosome number 2 $\mathrm{n}=18$ (Brutnell et al. 2015) (Table 2). It was domesticated in Northern parts of China nearly 9000-6000 years before the present. S. italica and $S$. viridis (wild) have a small genome size $(515 \mathrm{Mb})$, 
Table 2 Chromosome number, genotype sequenced, genome sizes, and number of genes in some millets

\begin{tabular}{|c|c|c|c|c|c|}
\hline $\begin{array}{l}\text { Name of the } \\
\text { millet }\end{array}$ & $\begin{array}{l}\text { Chromosome } \\
\text { number }\end{array}$ & $\begin{array}{l}\text { Genotype } \\
\text { sequenced }\end{array}$ & Proximate genome size & $\begin{array}{l}\text { Proximate number } \\
\text { of genes }\end{array}$ & References \\
\hline \multirow[t]{2}{*}{ Pearl millet } & $\begin{array}{l}2 \mathrm{n}=2 \mathrm{x}=14 \\
\text { (Diploid) }\end{array}$ & - & - & - & Martel et al. (1997) \\
\hline & - & Tift $23 \mathrm{D}_{2} \mathrm{~B}_{1}-\mathrm{P} 1-\mathrm{P} 5$ & $1.79 \mathrm{~Gb}$ & 38,579 & Varshney et al. (2017) \\
\hline \multirow[t]{4}{*}{ Finger millet } & $\begin{array}{l}2 n=4 x=36 \\
\text { AABB }\end{array}$ & - & - & - & $\begin{array}{l}\text { Bisht and Mukai } \\
\text { (2001) }\end{array}$ \\
\hline & (Tetraploid) & ML-365 & $1196 \mathrm{Mb}$ & 85,243 & $\begin{array}{l}\text { Hittalmani et al. } \\
\text { (2017) }\end{array}$ \\
\hline & & PR202 & $1500 \mathrm{Mb}$ & 62,348 & $\begin{array}{l}\text { Hatakeyama et al. } \\
\text { (2018) }\end{array}$ \\
\hline & & - & $1593 \mathrm{Mb}$ & - & $\begin{array}{l}\text { Goron and Raizada } \\
\text { (2015) }\end{array}$ \\
\hline \multirow[t]{3}{*}{ Foxtail millet } & $2 n=2 x=18$ & - & - & - & Wanous (1990) \\
\hline & (Diploid) & Yugu I & $510 \mathrm{Mb}$ & $24,000-29,000$ & $\begin{array}{l}\text { Bennetzen et al. } \\
\text { (2012) }\end{array}$ \\
\hline & & Zhang gu & $423 \mathrm{Mb}$ & 38,801 & Bhat et al. (2018) \\
\hline \multirow[t]{4}{*}{ Proso millet } & $2 n=4 x=36$ & - & - & - & Baltensperger (1996) \\
\hline & (Tetraploid) & Land race & $923 \mathrm{Mb}$ & 55,930 & Zou et al. (2019) \\
\hline & & $\begin{array}{l}\text { Accession No. } \\
00000390\end{array}$ & $887.8 \mathrm{Mb}$ & 63,671 & Zou et al. (2019) \\
\hline & & Longmi4 & $1020.5 \mathrm{Mb}$ & - & $\begin{array}{l}\text { Kubesova et al. } \\
\text { (2010) }\end{array}$ \\
\hline Little millet & $\begin{array}{l}2 n=4 x=36 \\
\text { (Tetraploid) }\end{array}$ & - & - & - & Wanous (1990) \\
\hline \multirow[t]{3}{*}{ Kodo millet } & $2 n=4 x=40$ & - & - & - & Burton (1940) \\
\hline & (Tetraploid) & & & & $\begin{array}{l}\text { Hiremath and Dandin } \\
\text { (1975) }\end{array}$ \\
\hline & & Not known & $1.91-1.98 \mathrm{Mb}$ & Not known & Jarret et al. (1995) \\
\hline \multirow{3}{*}{$\begin{array}{l}\text { Indian Barnyard } \\
\text { millet }\end{array}$} & $2 \mathrm{n}=6 \mathrm{x}=54$ & - & - & - & Wanous (1990) \\
\hline & (Allohexaploid) & & & & $\begin{array}{l}\text { Renganathan et al. } \\
\text { (2020) }\end{array}$ \\
\hline & & - & $2.7 \mathrm{Mb}$ & Not known & $\begin{array}{l}\text { Abrahamson et al. } \\
\text { (1973) }\end{array}$ \\
\hline $\begin{array}{l}\text { Japanese } \\
\text { Barnyard } \\
\text { millet }\end{array}$ & $\begin{array}{l}2 \mathrm{n}=6 \mathrm{x}=54 \\
\quad(\text { Allohexaploid })\end{array}$ & - & - & - & $\begin{array}{l}\text { Renganathan et al. } \\
\text { (2020) }\end{array}$ \\
\hline \multirow[t]{3}{*}{ Teff millet } & $2 n=4 x=40$ & - & - & - & Hundera et al. (2000) \\
\hline & (Allotetraploid) & $\begin{array}{l}\text { Tsedey cultivar } \\
\text { (DZ-Cr-37) }\end{array}$ & $\begin{array}{l}772 \text { Mbrepresenting } 87 \% \text { of the } \\
\text { total tef genome size }\end{array}$ & Not known & $\begin{array}{l}\text { Cannarozzi et al. } \\
\text { (2014) }\end{array}$ \\
\hline & & Land race Dabbi & $622 \mathrm{Mb}$ & 68,255 & $\begin{array}{l}\text { VanBuren et al. } \\
(2020)\end{array}$ \\
\hline \multirow[t]{3}{*}{ Fonio millet } & $\begin{array}{l}2 \mathrm{n}=4 \times=36 \\
\text { (Allotetraploid) }\end{array}$ & - & - & - & $\begin{array}{l}\text { Adoukonou-Sagbadja } \\
\text { et al. (2007) }\end{array}$ \\
\hline & & $\begin{array}{l}\text { Accession number } \\
\text { CM05836 }\end{array}$ & $893 \mathrm{Mb}$ & 57,021 & Abrouk et al. (2020) \\
\hline & & Niatia v1.0 & $760.66 \mathrm{Mb}$ & $\begin{array}{r}67,855 \text { (protein } \\
\text { coding genes) }\end{array}$ & Wang et al. (2021) \\
\hline
\end{tabular}


short life-cycle with a high potential for abiotic stress tolerance. The crop is grown in 26 countries including China, India, Bangladesh, Syria, and Africa, and ranks second in total world production of millets with 6 million tons of food in Europe, and Asia (Nadeem et al. 2018). It contains high $\mathrm{Zn}$ that can boost immunity in humans. Regular consumption of foxtail millet helps to fight diseases like osteoporosis and reduce the risk of bone fracture. It regulates cardiac function, Alzheimer's disease, enhances memory, and helps to strengthen muscles (Sharma and Niranjan 2018).

(d) Panicum miliaceum (Proso millet)

Proso millet or Broomcorn millet or Hog millet or Hershey millet or Common millet or Russian millet is the first domesticated tetraploid $(2 \mathrm{n}=4 \mathrm{x}=36)$ millet (Hunt et al. 2014) (Table 2). It is cultivated in half a million acres of semi-arid regions of China, India, Nepal, Russia, Ukraine, Belarus, Turkey, Romania, and the United States of America (Yang et al. 2019). The crop was first domesticated before $10,000 \mathrm{BCE}$ in the Northern parts of China, and the estimated genome sequence is around 920 megabases (Zou et al. 2019). It is a gluten-free, warm seasonal crop used as human food, feed for birds, forage, and bioprocessing purposes (Yang et al. 2019), and has significant amounts of essential amino acids.

(e) Panicum sumatrense (Little millet)

Panicum sumatrense (Little millet or Indian millet) is grown in both tropical and temperate zones, cultivated in China, India, Malaysia, East Asia, and the Caucasus, and can sustain both waterlogging and drought conditions. It is a tetraploid with a chromosome number of $2 \mathrm{n}=4 \mathrm{x}=36$ (Table 2 ) and domesticated in India as a part of tribal agriculture (de Wet et al. 1983). Grains are highly nutritious, used for the consumption of humans, as birdseed, and for alcohol production. It has $350 \mathrm{mg}$ of calcium per $100 \mathrm{~g}$ of seed weight which is 8-times higher than wheat (Srilekha et al. 2019). It is used as fodder for cattle and also for alcohol production (Kumar et al. 2016).

(f) Paspalum scrobiculatum (Kodo millet)

Native Paspalum or Kodo millet or Ditch millet or Cow grass or Rice grass or Indian crown grass, African bastard millet grass is native to South America and domesticated 3000 years ago in India (de Wet et al. 1983). Paspalum scrobiculatum var. scrobiculatum is a tetraploid species $(2 \mathrm{n}=4 \mathrm{x}=40)$ and grows in India (Table 2), while Paspalum scrobiculatum var. commersonii is the wild relative indigenous to Africa (Heuze et al. 2015). In India, it grows in Kerala, Tamil Nadu, Rajasthan, Uttar
Pradesh, and West Bengal, cooked as flour in India and whole grain in Africa and used as animal fodder for cattle, goats, pigs, sheep, and poultry. It has the highest dietary fiber among cereals (Mohamed et al. 2009) and contains lecithin that aids in strengthening the nervous system. A small amount of prussic acid has been found in leaves and kernels. Crude extracts of leaves have antifungal and tranquilizing activities (Mishra et al. 2000).

(g) Echinochloa esculenta (Japanese barnyard millet) and E. frumentaceae (Indian barnyard millet)

Barnyard millet or Japanese barnyard millet) mainly grows in Japan, India, China as food and fodder with a maturation time of around 50-70 days (Hulse et al. 1980). The genus Echinochloa is an allohexaploid with $2 \mathrm{n}=6 \mathrm{x}=54$ chromosomes (Table 2) and has two species, one is E. esculenta and another $E$. frumentaceae. This millet is grown in some pockets of India, Pakistan, and Nepal. Barnyard millet has the lowest carbohydrate and the highest crude fiber (13.6 g/100 g) (Saleh et al. 2013). The iron content is more than the daily recommended dietary allowance in men $(8.7 \mathrm{mg}$ ) and women (14.8 $\mathrm{mg}$ ) aged between 19 and 50 years. It is a domesticated millet in the semi-arid tropics of Asia and Africa, with 8,000 accessions available in Japan and India. In India, ICRISAT Genebank conserves 749 accessions (Upadhyaya et al. 2014). Japanese barnyard millet contains antioxidative phenolic acids such as $\mathrm{N}$-(p-coumaroyl) serotonin, luteolin and tricin (flavonoids). While the antioxidative activity of luteolin is equal to that of quercetin, tricine activity is lower than that of luteolin (Watanabe 1999). Besides serotonins, phytates, phenols, and tannins contribute to the antioxidant activity. Antioxidative molecules keep up human health, slow down the process of aging and maintain proper metabolism.

(h) Eragrostis tef (Zucc.) Trotter or teff millet

Eragrostis tef (Zucc.) Trotter or teff is a selfpollinated, warm-season millet. It is an allotetraploid $(2 \mathrm{n}=4 \mathrm{x}=40)$ species (Table 2), originated in the Horn of Africa, and grows in marginal soils under low rain-fed conditions in arid and semi-arid regions (Tadele and Assefa 2012). In Ethiopia, the yields of teff are low with an average of 1.7 tons per hectare (Cochrane and Bekele 2018). It is cultivated in 2.9 million hectares, with an average production of 4.5 million tons (Numan et al. 2021). Teff is a glutenfree, nutraceutical food, rich in carbohydrates $(57.27 \%)$, protein $(20.9 \%)$, fat $(0.5 \%)$, fiber $(2.8 \%)$, and amino acids $(8.15 \%)$. Seeds of teff are $22 \%$ rich in unsaturated fatty acids $(72.46 \%)$, with oleic and linolenic acid contents in fairly good amounts 
( $32.41 \%$ and $23.83 \%$ respectively). The seed oil contains anti-hyperlipidemic and anti-hyperglycemic activities (El-Alfy et al. 2012). Teff contains flavonoids, saponins, tannins, glycosides, and steroids, and grains have been recommended against celiac disease (triggered by eating gluten), hypertension, anemia, diabetes, and cancer (Akansha and Chauhan 2020).

(i) Digitaria exilis (Kippist) Stapf and Digitaria iburu Stapf or fonio millet

Digitaria exilis (Kippist) Stapf and Digitaria iburua Stapf are known as white and black fonio millets respectively (husks are white and dark brown in colour and hence the names). They are African orphan millets, with a very short life cycle and are often referred to as women's crop (Haq and Ogbe 1995; Small 2015). They are domesticated by West African tribes in marginal lands as staple food dating back to 5 millennia BC (Murdock 1959; Larson et al. 2014). Digitaria exilis is an allotetraploid (Table 2), and the number of chromosomes is $2 \mathrm{n}=4 \mathrm{x}=36$ (Adoukonou-Sagbadja et al. 2007). Seeds of fonio are called the "grain of life" since they have good culinary and nutritional properties. Grains of both $D$. exilis and D. iburua are glutenfree, containing 74.4 and $75.6 \mathrm{~g}$ of carbohydrates, 7.1 and $8.9 \mathrm{~g}$ of protein per $100 \mathrm{~g}$ of seed weight, and 7.4 and $6.2 \mathrm{~g}$ dietary fiber respectively (Vodouhe et al. 2007). Grains are rich in sulphur containing essential amino acids like methionine and cystine, cure coeliac disease, good for lactating women and also diabetic patients. Abrouk et al. (2020) established high-quality genomic resources including chromosome-scale reference assembly as well as deep re-sequencing of 183 cultivated and wild species which ultimately helps its improvement through molecular breeding.

Millets serve as a natural source of antioxidants in food applications and also as a nutraceutical, abode highly valued mineral elements like $\mathrm{Ca}^{2+}, \mathrm{K}^{+}, \mathrm{Fe}^{2+}, \mathrm{Zn}^{2+}$, and $\mathrm{Se}$, besides vitamins, essential fatty acids, amino acids, and antioxidative compounds (Table 2). Cultivation of millets in dry or marginal lands makes them productive and at the same time ensures the security of food and nutrition to the future generations especially under climate-smart agriculture (Chandel et al. 2014; Kumar et al. 2018). Given their health benefits, their daily usage must be promoted for the well-being of society especially in resource-poor areas.

\section{Biofortification of minerals in millets}

Stunting, wasting, and being underweight/overweight are some of the indicators of malnutrition globally in children. Nearly half of the children in Asian continent are affected by wasting live. Similarly, half of the countries have experienced overweight (UNICEF/WHO/The World Bank 2021). Fe and $\mathrm{Zn}$ deficiencies are widespread and affect 2 billion people on the global scale (Webb et al. 2018). Among African populations, the risk for micronutrient deficiencies is $54 \%$ for $\mathrm{Ca}^{2+}, 40 \%$ for $\mathrm{Zn}, 28 \%$ for $\mathrm{Se}, 19 \%$ for iodine, and $5 \%$ for Fe (Joy et al. 2014). Fe deficiency can lead to severe microcytic anemia and impaired immune function (Bailey et al. 2015). These circumstances necessitate addressing the problem of malnutrition immediately by producing staple food crops like millets with enriched minerals and also their accessibility to the mal/undernourished. Biofortification is an economically feasible food-based strategy to address the problem of "hidden hunger" by bringing nutrient-dense crops to the doorsteps of the under- and malnourished in resource-poor areas (Bouis et al. 2011). The Harvest Plus-Consultative Group for International Agricultural Research (CGIAR) Micronutrients project's Biofortification Challenge Program (BCP) has targeted seven major staple crops with three important micronutrients like $\mathrm{Fe}, \mathrm{Zn}$, and vitamin $\mathrm{A}$ (Welch and Graham 2004). Fe and Zn deficiencies are the most significant, impacting more than three billion people worldwide specifically from underdeveloped countries (Chasapis et al. 2012; Webb et al. 2018; Kramer and Allen 2015). Pearl millet outperforms rice and wheat in terms of nutritional values like fibre, $\mathrm{Ca}^{2+}, \mathrm{Fe}^{2+}, \mathrm{Zn}^{2+}$, phosphorous $(\mathrm{P})$, and potassium $\left(\mathrm{K}^{+}\right)$contents (Saleh et al. 2013). They grow and perform well under dry, semi-arid, and drought-prone environments. Millets have been chosen as an attractive option for genetic improvement of biofortification since they form as staple sources of calories/energy in resource-poor countries of Africa and Asia, mainly in rural areas (Vijayakumari et al. 2003; Manwaring et al. 2016).

\section{Strategies to improve biofortification and exploitation of natural genetic variation}

To develop biofortified crops, (a) screening the genetic resources for high and low micronutrient contents (b) supplementation of minerals as organic supplements/manure into the soil (c) foliar application (d) traditional plant breeding methods, and speed breeding, (e) molecular breeding including high-throughput genomics, phenotyping, and (f) transgenic/genome-editing approaches (g) improved uptake and transport of micronutrients, nitrogen, 
phosphorous, and photoassimilates to the grain filling site (Fig. 1) are the options that can accelerate micronutrient densities in millet grains (Bouis and Welch 2010; Manwaring et al. 2016). In pearl millet, variability existed for $\mathrm{Fe}$ and $\mathrm{Zn}$ were $35-116 \mathrm{mg} / \mathrm{kg}, 21-80 \mathrm{mg} / \mathrm{kg}$ respectively while protein varied from 6 to $18 \%$ (Pujar et al. 2020). Similarly, $\mathrm{Zn}$ concentrations in finger millet were assessed and the content ranged from 10 to $86 \mu \mathrm{g} / \mathrm{g}$ weight of grains among the 319 genotypes (Yamunarani et al. 2016). Their results indicate the success of screening and breeding programs for high $\mathrm{Fe}$ and $\mathrm{Zn}$ utilizing genetic variability. So, germplasm for all millets must be screened first for genetic diversity in grain nutrients especially $\mathrm{Fe}^{2+}, \mathrm{Zn}^{2+}$, $\mathrm{Se}, \mathrm{Ca}^{2+}$, copper and iodine, and then such a natural variation must be exploited by breeding/speed breeding methods. Using breeding strategies, pearl millet, and finger millet hybrid lines with high $\mathrm{Fe}(70-75 \mathrm{mg} / \mathrm{kg}$ ), $\mathrm{Zn}$ $(35-40 \mathrm{mg} / \mathrm{kg}$ ) densities have been evolved in India in the background of high yielding character (Govindaraj et al. 2019). Variability in the mineral content exists in the wealth of natural germplasm, but foxtail, kodo, barnyard, teff, and fonio millets did not receive much attention for biofortification though they are being consumed by many in Asia and Africa. To achieve effective biofortification of $\mathrm{Fe}^{2+}, \mathrm{Zn}^{2+}, \mathrm{Se}$, and any other micronutrients, molecular breeding, genetic engineering, genome editing coupled with novel agronomic and edaphic management strategies are essential. Such a game plan is imperative for genetic gains.

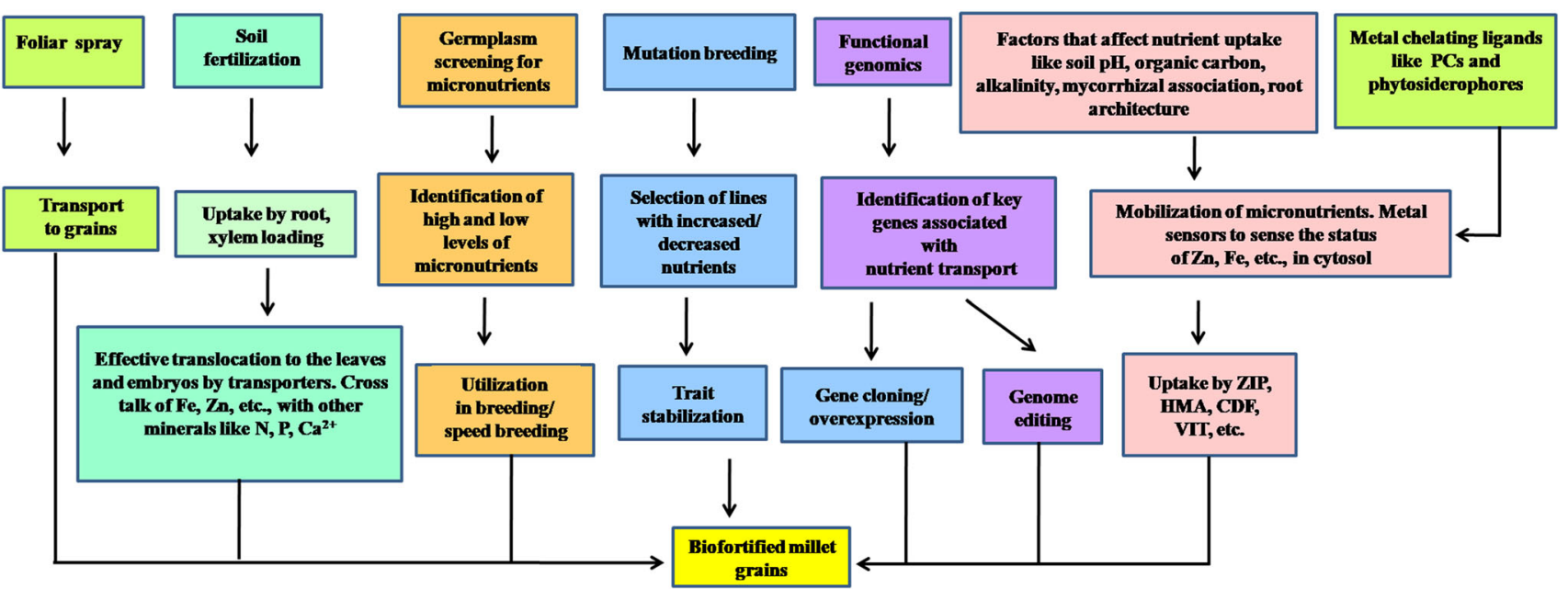

Fig. 1 Strategies that affect accumulation of micronutrients in millets. Diverse strategies like screening the germplasm for high micronutrient content, foliar spray, soil fertilization, traditional breeding/molecular breeding methods, and genetic engineering

\section{Biofortification of $\mathrm{Ca}^{2+}, \mathrm{Se}$, and iodine}

Besides $\mathrm{Fe}$ and $\mathrm{Zn}, \mathrm{Ca}^{2+}$ is another important nutrient that provides vascular and muscular contractions, nerve signal transmissions, and fights against osteoporosis. It is essential for protection against breast, colorectal, and prostate cancers (Puranik et al. 2017) and for reduction of adipose tissue, body weight, and diabetes (Parikh and Yanovski 2003; Oei et al. 2013). They assessed some of the challenges associated with $\mathrm{Ca}^{2+}$ biofortification in finger millet, it being a rich source. But we still do not have complete knowledge about the potential risks of improving $\mathrm{Ca}^{2+}$ levels in millets and weigh it out against the potential benefits and associated changes in the antinutrients which need to be taken care of. There is a need to find out about consumer acceptability coupled with sensory satisfaction with enhanced levels of $\mathrm{Ca}^{2+}$ and micronutrients in the millets. Furthermore, market avenues for such special grains with improved nutritional quality (varieties and hybrids) do not exist now, therefore, Governmental organizations and private seed companies need to devise strategies for marketing to address malnutrition (Yadav et al. 2021). Consumption of biofortified pearl millet improved the cognitive outcomes in adolescents with an increase in the bioavailability of $\mathrm{Fe}$ and $\mathrm{Zn}$ in studies conducted in few states of India (Kodkany et al. 2013), but not from other millets. Similarly, the focus so far has been like $\mathrm{Se}, \mathrm{Cu}^{2+}, \mathrm{Mn}^{2+}$, and iodine. Se is an indispensable element and its deficiency is a key problem globally. on improving $\mathrm{Fe}^{2+}$ and $\mathrm{Zn}^{2+}$, but not other micronutrients approaches help biofortification of millet grains. $\mathrm{Ca}^{2+}-$ calcium, $\mathrm{CDF}$ - cation diffusion facilitator, Fe-iron, HMA-heavy metal ATPase, $\mathrm{N}$-nitrogen, $\mathrm{P}$ - phosphorous, $\mathrm{PCs}$ - phytochelatins, VITvacuolar iron transporter, $\mathrm{Zn}$-zinc, ZIP-zinc-iron-permease 
Millets accumulate Se; therefore, they are a rich source of Se nutrition to the consumers. Foliar application of sodium selenite $\left(\mathrm{Na}_{2} \mathrm{SeO}_{3}\right)$ in foxtail millet has been investigated by Liang et al. (2020) which has resulted in 9.8-fold enhancement in selenomethionine and selenocysteine with a concurrent increase in $\mathrm{K}^{+}$and $\mathrm{Fe}$ content. The results infer Se-inducible proteins in foxtail millet that could be useful Se-enriched millets in the years to come. To biofortify Se in millets, nanosized biofortification, and supplementation with multiple micronutrients are recommended (Schiavon et al. 2020). Breeding strategies using high Se lines must be adapted as an alternative approach. Since $\mathrm{Fe}^{2+}, \mathrm{Zn}^{2+}$, and $\mathrm{Se}$ are an immune boosters, if biofortified food can be used against Corona virus disease or not needs further investigations. Another important micronutrient that is essential to humans is iodine (I), associated with thyroid hormone synthesis, which in turn control metabolism and brain development during pregnancy. Based on the available literature, it appears that the best method for improving Se and iodine is foliar fertilization with $\mathrm{Se}(\mathrm{VI})$ as a source (Izydorczyk et al. 2021). The experiments conducted thus far indicate that iodosalicylates and iodobenzoates are ideal for the fortification of iodine. So, millets can be biofortified for iodine and used for promoting human health.

\section{Antinutrients and bioavailability of micronutrients}

On the flip side, antinutrients like phytates, polyphenols, protease inhibitors, and tannins limit the mineral accessibility in humans by conjugating multivalent cations like $\mathrm{Fe}^{2+}, \mathrm{Zn}^{2+}, \mathrm{Ca}^{2+}, \mathrm{Mg}^{2+}$, and $\mathrm{K}^{+}$(AbdelRahman et al. 2005). Phytate, tannins, oxalates, non-starch polysaccharide glucans affect the digestibility and decrease the bioavailability of $\mathrm{Fe}, \mathrm{Zn}$ and others. To overcome such issues, strategies like soaking the seeds, autoclaving, debranning, and supplementation of enzymes are being deployed (Tharifkhan et al. 2021). Further, the germplasm of millets has been underutilized, but core collections representing the genetic diversity need to be screened for low levels of antinutrients (Kumar et al. 2016). So, strategies need to be designed specifically to reduce antinutrients like phytate on one hand and to improve the bioavailability of minerals on the other in minor millets. The ICRISAT biofortification program is pursuing a goal by supporting existing high-Fe hybrid parents and advanced breeding lines acquired from the mainstream breeding strategy to generate high-yielding, high-Fe hybrids. De Moura et al. (2014) conducted human trials with staple food crops biofortified by breeding methods. Fe-biofortification interventions among women and children have significantly improved the Fe status, hemoglobin levels, and serum ferritin concentrations. These experiments indicate that iron-biofortification is efficacious in improving $\mathrm{Fe}$ status in the target group who are Fe-deficient. The same groups have also carried out trials using biofortified vitamin A staple crops. The results suggest a positive impact on the functional outcome (De Moura et al. 2014). However, challenges exist in sustainable interventional trials that need to be undertaken on a larger scale among target populations, especially in the resource-poor countries. The experiments also reveal that the bioavailability of $\mathrm{Fe}$ and $\mathrm{Zn}$ is not a barrier if biofortified millets have to be fed to the target groups.

\section{Mineral uptake and translocation for improved accumulation}

For the grains to accumulate micronutrients, transportation of micronutrients and photosynthates from the leaf to the grain filling site is highly crucial. Studies on $\mathrm{Zn}$ translocation in 12 finger millet genotypes revealed wide variation in root uptake and transport depending upon the genotypes (Yamunarani et al. 2016). This clearly underlies the importance of variation for uptake and translocation of minerals and also the opportunities to improve grain $\mathrm{Zn}$ nutrition using breeding programs. Therefore, natural genetic diversity for $\mathrm{Fe}$ and $\mathrm{Zn}$ uptake in millets needs to be screened and identified for subsequent utilization. Conditions such as soil redox potential and $\mathrm{pH}$, influence mineral nutrient availability. Fe is rapidly oxidized in soils at higher $\mathrm{pH}$ levels, resulting in insoluble ferric oxides. In contrast, at lower $\mathrm{pH}$, ferric $\mathrm{Fe}$ is liberated from the oxide, making it accessible for root uptake via the action of a ferric chelate reductase (Marschner and Rimmington 1988). Calcium, calmodulin, and other signal components involved in the signaling networks, and transport of micronutrients and calcium (CAX transporters) to the grain filling site are shown in the Fig. 2. Zhao and McGrath (2009) noticed that $\mathrm{Fe}$ and $\mathrm{Zn}$ transporters also transport toxic metals like that of Cd. AtIRT1, a divalent metal transporter of the ZIP family, transports Fe into root epidermal cells along with $\mathrm{Zn}, \mathrm{Mn}, \mathrm{Cn}$, and Ni micronutrients (Korshunova et al. 1999; Krishna et al. 2020). Fe flows into the xylem with the help of citrate complex and subsequently transports into the phloem using nicotianamine (NA) and YELLOW STRIPE-LIKE (YSL) transporters (Morrissey and Guerinot 2009) (Fig. 2). NA transporters play a key role in metal homeostasis and help in the movement of $\mathrm{Fe}$ in and out of the phloem via YSL transporters. Since they bind with $\mathrm{Cu}^{2+}, \mathrm{Ni}^{2+}, \mathrm{Co}^{2+}, \mathrm{Zn}^{2+}$, and $\mathrm{Mn}^{2+}$ (Curie et al. 2009), their role as transporters of multiple nutrients must be recognized. Hence, improving $\mathrm{Fe}$ content in millets, may concomitantly improve the 


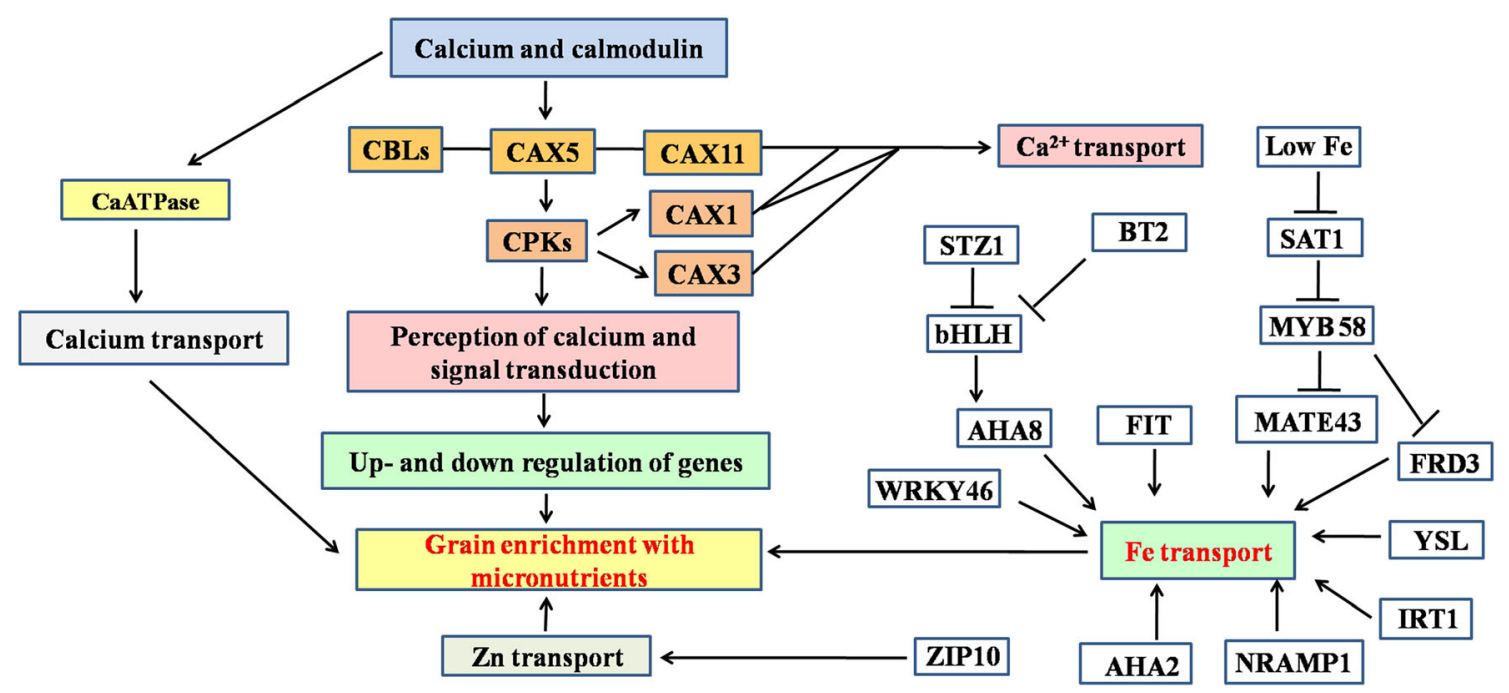

Fig. 2 Calcium, calmodulin and other signal components involved in the signaling networks, and transport of micronutrients to the grain filling site. AHA-plasma membrane $\mathrm{H}^{+}$ATPase, BT-E3 ligase, bHLH-basic helix-loop-helix, CaATPase-calcium ATPase, $\mathrm{CAX}$ - cation $/ \mathrm{H}^{+}$transporter, $\mathrm{CBL}$-calcineurin $\mathrm{B}$-like protein, CPK - calcium-dependent protein kinase, FIT-FER-like iron deficiency-induced transcription factor, FRD-FERRIC REDUCTASE

concentrations of other minor nutrients like $\mathrm{Cu}^{2+}, \mathrm{Ni}^{2+}$, $\mathrm{Co}^{2+}$, and $\mathrm{Mn}^{2+} \cdot \mathrm{Zn}^{2+}$ is an essential micronutrient and is available in water soluble form with +2 oxidation state. $\mathrm{Zn}^{2+}$ and $\mathrm{Fe}^{2+}$ uptake always compete for NA transporters. $\mathrm{Zn}^{2+}$ transport is mediated by a family of ZIP transporters (Fig. 2) from the epidermal cell to xylem via a symplastic pathway and move towards the phloem (Olsen and Palmgren 2014). Besides aiding $\mathrm{Zn}$ uptake, zinc-regulated, ironregulated transporter-like protein (ZIP) family members like $I R T_{1}$ and $I R T_{2}$ also help in Cd uptake (Guerinot 2000), hence caution must be exercised. Se is a vital micronutrient for living organisms as it performs a role in a number of physiological and metabolic processes. Plants are the primary dietary source of Se for humans, since many species may metabolize and accumulate organic Se in edible portions that can be ingested in native or processed forms. Various research findings have explored for Se biofortification of plants in order to develop Se-enriched products and induce Se production (D'Amato et al. 2020). Plantbased Se biofortification has many advantages over the direct Se supplementation as an inorganic form of Se [selenide $\left(\mathrm{Se}^{2-}\right)$, selenite $\left(\mathrm{SeO}_{2}-3 \mathrm{SeO}_{3}{ }^{2-}\right)$, and selenate $\left.\left(\mathrm{SeO}_{2}-4 \mathrm{SeO}_{4}{ }^{2-}\right)\right]$ is converted to organic form (SeMet and SeCys). While selenite uptake is via phosphate transporters ( $\mathrm{Li}$ et al. 2008), selenate is transported through sulfate transporters like SULTR1 and SULTR1;2 (Takahashi and Saito 2008). Se biofortified plants exhibit high levels of minerals and antioxidants (D'Amato et al. 2020). Since transporters are known, efforts must now aim at improving their translocation and accumulation in the grains of
DEFECTIVE, IRT-iron regulated transporter, MATE-multidrug and toxin efflux, MYB-myeloblastosis transcription factor, NRAMP - natural resistance-assisted macrophages protein, SATsymbiotic ammonium transporter, SIZ1-SUMOE3 ligase, WRKYtranscription factors with a motif WRKYGQK at the N-terminus, YSL-yellow stripe 1-like transporter, ZIP-zinc-iron-permease

millets. Attempts must also be made to generate Se biofortified millets that are cost effective and accessible to the malnourished. Iodine is translocated as either iodide or iodate (Mackowiak and Grossl 1999). Both iodosalicylates and iodobenzoates have been found as excellent sources of iodine for the biofortification of Solanum lycopersicum (Halka et al. 2019). They studied the uptake of inorganic and organic sources of iodine and found that they are transported to tomato fruits. Among the compounds tested for transport, 2-iodobenzoic acid (2-IBeA) has been efficiently transferred to fruits in the form of iodine. Importantly, it has been found to accumulate in the soluble portions of cells. Inorganic and organic compounds applied to tomato plants have affected not only the expression of the $H M T$ gene (encodes halide ion methyltransferase), but also $S A M T$ and $S 3 H$ genes (encode salicylic acid carboxyl methyltransferase, and salicylic acid 3-hydroxylase) (Halka et al. 2019). However, these experiments need to be carried out in millets and if they can accumulate iodine, the complications that arise from thyroid during pregnancy can be resolved to a large extent. Importantly, any disruption due to drought and heat stress conditions can impair the uptake and translocation of mineral nutrients and subsequently the nutritional quality of the millet grains. Hence, we should make an endeavour to immediately address the challenges of grain nutritional quality in millets especially in the wake of climate change through traditional and molecular breeding approaches.

Scope exists therefore for the introduction of several candidate genes that alleviate abiotic stresses and at the 
same time improve nutritional quality especially grain $\mathrm{Fe}$, $\mathrm{Zn}$, and Se contents. Gaddameedi et al. (2020) studied heterosis and combining ability for grain $\mathrm{Fe}$ and $\mathrm{Zn}$ concentrations in Sorghum bicolor. Mahendrakar et al. (2020) identified 29 candidate genes related to $\mathrm{Fe}$ and $\mathrm{Zn}$ metabolism in pearl millet which exhibited tissue and developmental stage-specific patterns. These studies provide an insight into the cloning and overexpression of these genes for enhanced production of grain $\mathrm{Fe}$ and $\mathrm{Zn}$ and their use in breeding programs.

\section{Gene knockout studies and CRISPR gene editing}

Studies on CRISPR-Cas9 technology in millets and their improvement are scanty. But, CRISPR-Cas has been effectively employed in several cereal crops and therefore has the potential to boost the grain quality of small seed millets (Fiaz et al. 2019). Since the genome sequences of some of the millets are available, it is possible to identify the target genes for improving productivity alongside mineral nutrients. Genes implicated in higher yields, and grain nutritional qualities have been identified in major cereals, hence, their homologs can be detected in millets. Such genes can be exploited for the improvement of millets using CRISPR-Cas9 technology.

\section{Role of non-coding RNA (ncRNA) regulations into biofortification}

Given the limitation of studies on next-generation sequencing in lieu of trait-specific nutrition, there is always a need for strengthening the genetic and genomics screening approaches for better breeding efficiency traits (Vetriventhan et al. 2020). As the genetic variation is best seen in ncRNAs, identifying the differentially expressed genes (DEGs) plays an indispensable role in signaling mechanisms (Budak et al. 2020). Among the ncRNAs, microRNAs (miRNAs) are known to regulate the stress responses and also known to maintain nutritional homeostasis (Paul et al. 2015). The process of regulating the expression of transporters and nutrient homeostasis not only allows uptake of minerals but also ensures easy mobilization across the plant lumen. Studies have crept in towards understanding the regulatory mechanisms delineating the crop biofortification and they give dissipating results if the work is augmented on the trait-specific processes. Metal tolerance proteins are one such type of proteins associated at the subcellular level encoding proteins in the wheat genome, as most of the classes of proteins have $\mathrm{Zn}$ transporter/cis-regulatory domains or motifs. Several intergenic ncRNAs were discovered with their expression known in the aleurone layer of grains. As many of the millets are not annotated, they may have lncRNAs which could prove to be involved in biofortification. These can, however be better understood using amplicon-based targeted genome sequencing approaches. With an increased cereal $\mathrm{Fe} / \mathrm{Zn}$ content in wheat being studied to expedite the better breeding processes, efforts on seedling transcriptome analysis have given a big hope with several key transcripts associated with phytosiderophore biosynthesis and mineral uptake. It will be very insightful to see if any of these miRNA-DEGs would exhibit greater accumulation when there is a significant number of genes that are noticed in tandem. As more and more such whole seedling genome sequencing efforts come in, the biofortification-based ncRNA repertoire will hopefully allow us to have an enhanced understanding.

\section{Conclusions and road ahead}

Millets provide food security and prevent malnutrition during pandemics and also under dynamic climatic conditions. They grow easily even under harsh environments and are naturally tolerant to biotic and abiotic stresses. Millets are more nutritious than rice, wheat, and maize with better antioxidative capacity. Supplementation of minerals through fertilizers or foliar sprays must be deployed to enhance the content of mineral nutrition in millet grains. Further, their bioefficacy and bioavailability must be carefully undertaken in the target groups. Uptake and translocation are other important realms for which natural genetic diversity must be identified and exploited in all millets. Utilization of genetic resources, and genome sequences for the identification of candidate genes and their exploitation for the mineral nutrition improvement using CRISPR-Cas9 paves the way for food, feed, and nutritional security in the years to come.

Acknowledgements PBKK is thankful to the Vignan's Foundation for Science, Technology and Research for providing an Emeritus Fellowship.

Authors' contributions AKS has written about Paspalum scrobiculatum, and Setaria italica. HKP has written about Eleusine coracana, and Echinochloa esculentum. JN has written about Cenchrus americanus. RG and SE have written about introduction, Panicum miliaceum, Panicum sumatrense. PBK has written about teff, fonio and barnyard millets. RP, PS, DK and PBK have planned and collated the manuscript, edited and refined it. PS, HKP have prepared the figures. PBK has updated all sections and revised the manuscript.

Funding No funding is available for this work.

\section{Declarations}

Conflict of interest The authors declare no conflict of interest. 


\section{References}

AbdelRahman SM, Babiker EE, El Tinay AH (2005) Effect of fermentation on antinutritional factors and $\mathrm{HCl}$ extractability of minerals of pearl millet cultivars. J Food Technol 3:516-522

Abrahamson S, Bender MA, Conger AD et al (1973) Uniformity of radiation-induced mutation rates among different species. Nature 245:460-462. https://doi.org/10.1038/245460a0

Abrouk M, Ahmed HI, Cubry P et al (2020) Fonio millet genome unlocks African orphan crop diversity for agriculture in a changing climate. Nat Commun 11:4488. https://doi.org/10. 1038/s41467-020-18329-4

Adoukonou-Sagbadja H, Wagner C, Dansi A et al (2007) Genetic diversity and population differentiation of traditional fonio millet (Digitaria spp.) landraces from different agro-ecological zones of from West-Africa. Theor Appl Genet 115:917-931. https:// doi.org/10.1007/s00122-007-0618-x

Agricultural Statistics, GOI (2014) Pearl millet. In: Agricultural statistics at a glance-2014, Government of India. Oxford University Press, New Delhi, India, pp 85-86

Ajithkumar IP, Panneerselvam R (2014) ROS scavenging system, osmotic maintenance, pigment and growth status of Panicum sumatrense Roth. under drought stress. Cell Biochem Biophys 68:587-595. https://doi.org/10.1007/s12013-013-9746-x

Akansha CS, Chauhan ES (2020) Teff millet: nutritional, phytochemical and antioxidant potential. Int J Pharmaceut Sci Res 11:6005-6009. https://doi.org/10.13040/IJPSR.0975-8232. 11(12).6005-09

Allan CB, Lacourciere GM, Stadtman TC (1999) Responsiveness of selenoproteins to dietary selenium. Ann Rev Nutr 19:1-16. https://doi.org/10.1146/annurev.nutr.19.1.1

Anbukkani P, Balaji SJ, Nityashree ML (2017) Production and consumption of minor millets in India-a structural break analysis. Agric Res New Ser 38:1-8

Bailey RL, West KP Jr, Black RE (2015) The epidemiology of global micronutrient deficiencies. Ann Nutr Metab 66:22-33. https:// doi.org/10.1159/000371618

Baltensperger DD (1996) Foxtail and proso millet. In: Janick J, Whipkey A (eds) Trends in new crops and new uses. ASHS Press, Alexandria, pp 182-190

Barikmo I, Ouattara F, Oshaug A (2007) Differences in micronutrients content found in cereals from various parts of Mali. J Food Compos Anal 20:681-687. https://doi.org/10.1016/j.jfca.2007. 04.002

Bennetzen JL, Schmutz J, Wang H et al (2012) Reference genome sequence of the model plant Setaria. Nat Biotechnol 30:555-561. https://doi.org/10.1038/nbt.2196

Bhat BV, Tonapi VA, Rao BD et al (2018) Production and utilization of millets in India. In: Santra DK, Johnson JJ (eds) International millet symposium on 3rd international symposium on broomcorn millet (3rd ISBM), pp 24-36

Bisht MS, Mukai Y (2001) Genomic in situ hybridization identifies genome donor of finger millet (Eleusine coracana). Theor Appl Genet 102:825-832. https://doi.org/10.1007/s001220000497

Bouis HE, Welch RM (2010) Biofortification-a sustainable agricultural strategy for reducing micronutrient malnutrition in the global south. Crop Sci 50:20. https://doi.org/10.2135/ cropsci2009.09.0531

Bouis HE, Hotz C, McClafferty B et al (2011) Biofortification: a new tool to reduce micronutrient malnutrition. Food Nutr Bull 32:S31-S40. https://doi.org/10.1177/15648265110321S105

Brutnell TP, Bennetzen JL, Vogel JP (2015) Brachypodium distachyon and Setaria viridis: model genetic systems for the grasses. Annu Rev Plant Biol 66:465-485. https://doi.org/10. 1146/annurev-arplant-042811-105528
Budak H, Kaya SB, Cagirici HB (2020) Long non-coding RNA in plants in the era of reference sequences. Front Plant Sci 11:276. https://doi.org/10.3389/fpls.2020.00276

Burton GW (1940) A cytological study of some species in the genus Paspalum. J Agric Res 60:193-198

Cannarozzi GM, Wuthrich SP, Esfeld K et al (2014) Genome and transcriptome sequencing identified breeding targets in the orphan crop tef (Ergrostis tef). BMC Genom 15:581. https:// doi.org/10.1186/1471-2164-15-581

Chandel G, Kumar M, Dubey M et al (2014) Nutritional properties of minor millets: neglected cereals with potentials to combat malnutrition. Curr Sci 107:1109-1111

Chasapis CT, Loutsidou AC, Spiliopoulou CA et al (2012) Zinc and human health: an update. Arch Toxicol 86:521-553. https://doi. org/10.1007/s00204-011-0775-1

Cheng A, Mayes S, Dalle G et al (2017) Diversifying crops for food and nutrition security - a case of teff. Biol Rev Camb Philos Soc 92:188-198. https://doi.org/10.1111/brv.12225

Cochrane L, Bekele YW (2018) Average crop yield (2001-2017) in Ethiopia: trends at national, regional and zonal levels. Data Brief 16:1025. https://doi.org/10.1016/j.dib.2017.12.039

Curie C, Cassin G, Couch D et al (2009) Metal movement within the plant: contribution of nicotianamine and yellow stripe 1-liketransporters. Ann Bot 103:1-11. https://doi.org/10.1093/aob/ $\operatorname{mcn} 207$

D’Amato R, Regni L, Falcinelli B et al (2020) Current knowledge on selenium biofortification to improve the nutraceutical profile of food: a comprehensive review. J Agric Food Chem 68:4075-4097. https://doi.org/10.1021/acs.jafc.0c00172

Das S, Khound R, Santra M et al (2019) Beyond bird feed: proso millet for human health and environment. Agriculture 9:64. https://doi.org/10.3390/agriculture9030064

De Moura FF, Palmer AC, Finkelstein JL et al (2014) Are biofortified staple food crops improving vitamin A and iron status in women and children? New evidence from efficacy trials. Adv Nutr 5:568-570. https://doi.org/10.3945/an.114.006627

de Wet JMJ, Rao KEP, Mengesha MH et al (1983) Diversity in kodo millet, Paspalum scrobiculatum. Econ Bot 37:159-163. https:// doi.org/10.1007/bf02858779

El-Alfy TS, Ezzat SM, Sleem AA (2012) Chemical and biological study of the seeds of Eragrostis tef (Zucc.) Trotter. Nat Prod Res 26:619-629. https://doi.org/10.1080/14786419.2010.538924

FAOSTAT (2019) http://www.fao.org/faostat/en/\#data/QC/visualize. Accessed 2 Jan 2021

Fernandez DR, Vanderjagt DJ, Millson M et al (2003) Fatty acid, amino acid and trace mineral composition of Eleusine coracana (Pwana) seeds from northern Nigeria. Plant Foods Hum Nutr 58:1-10. https://doi.org/10.1023/B:QUAL.0000040323.67339. $\mathrm{cb}$

Fiaz S, Ahmad S, Noor MA et al (2019) Applications of the CRISPR/ Cas9 system for rice grain quality improvement: perspectives and opportunities. Int J Mol Sci 20:888. https://doi.org/10.3390/ ijms20040888

Gaddameedi A, Phuke RM, Kavi Kishor PB et al (2020) Heterosis and combining ability for grain $\mathrm{Fe}$ and $\mathrm{Zn}$ concentration and agronomic traits in sorghum [(Sorghum bicolor (L.) Moench]. J King Saud Univ Sci 32:2989-2994. https://doi.org/10.1016/j. jksus.2020.08.003

Gebru YA, Sbhatu DB, Kim KP (2020) Nutritional composition and health benefits of teff (Eragrostis tef (Zucc.) Trotter). J Food Qual 2020:1-6. https://doi.org/10.1155/2020/9595086

Goron TL, Raizada MN (2015) Genetic diversity and genomic resources available for the small millet crops to accelerate a new green revolution. Front Plant Sci 6:157. https://doi.org/10.3389/ fpls.2015.00157 
Govindaraj M, Rai KN, Cherian B et al (2019) Breeding biofortified pearl millet varieties and hybrids to enhance millet markets for human nutrition. Agriculture 9:106. https://doi.org/10.3390/ agriculture 9050106

Guerinot ML (2000) The ZIP family of metal transporters. Biochim Biophys Acta 1465:190-198. https://doi.org/10.1016/S00052736(00)00138-3

Habiyaremye C, Matanguihan JB, D'Alpoim Guedes J et al (2017) Proso millet (Panicum miliaceum L.) and its potential for cultivation in the Pacific Northwest, US: a review. Front Plant Sci 7:1961. https://doi.org/10.3389/fpls.2016.01961

Halka M, Smoleń S, Czernicka M et al (2019) Iodine biofortification through expression of HMT, SAMT and S3H genes in Solanum lycopersicum L. Plant Physiol Biochem 144:35-48. https://doi. org/10.1016/j.plaphy.2019.09.028

Haq N, Ogbe DF (1995) Fonio (Digitaria exilis and Digitaria iburua). In: Williams JT (ed) Cereals and pseudocereals. Chapman \& Hall, London, pp 225-245

Hatakeyama M, Aluri S, Balachadran MT et al (2018) Multiple hybrid de novo genome assembly of finger millet, an orphan allotetraploid crop. DNA Res 25:39-47. https://doi.org/10.1093/ dnares/dsx036

Heuze V, Tran G, S Giger-Reverdin (2015) Scrobic (Paspalum scrobiculatum) forage and grain feedipedia-a programme by INRA, CIRAD, AFZ and FAO. http://www.feedipedia.org/node/ 401

Himanshu, Chauhan M, Sonawane SK et al (2018) Nutritional and neutraceutical properties of millets: a review. Clin J Nutr Diet $1: 1-10$

Hiremath SC, Dandin SB (1975) Cytology of Paspalum scrobiculatum Linn. Curr Sci 44:20-21

Hittalmani S, Mahesh HB, Shirke MD et al (2017) Genome and transcriptome sequence of finger millet (Eleusine coracana (L.) Gaertn.) provides insights into drought tolerance and nutraceutical properties. BMC Genom 18:465. https://doi.org/10.1186/ s12864-017-3850-z

Hulse JH, Laing EM, Pearson OE (1980) Sorghum and the millets: their composition and nutritive value. Academic Press, New York

Hundera F, Arumuganathan K, Baenziger P (2000) Determination of relative nuclear DNA content of tef [Eragrostis tef (Zucc.) Trotter] using flow cytometry. J Genet Breed 54:165-168

Hunt HV, Badakshi F, Romanova O et al (2014) Reticulate evolution in Panicum (Poaceae): the origin of tetraploid broomcorn millet, P. miliaceum. J Exp Bot 65:3165-3175. https://doi.org/10.1093/ jxb/eru161

Izydorczyk G, Ligas B, Mikula K et al (2021) Biofortification of edible plants with selenium and iodine-a systematic literature review. Sci Total Environ 754:141983. https://doi.org/10.1016/j. scitotenv.2020.141983

Jarret RL, Ozias-Akins P, Phatak S et al (1995) DNA contents in Paspalum spp. determined by flow cytometry. Genet Resour Crop Evol 42:237-242. https://doi.org/10.1007/BF02431258

Joy EJM, Ander EL, Young SD et al (2014) Dietary mineral supplies in Africa. Physiol Plant 151:208-229. https://doi.org/10.1111/ ppl.12144

Kodkany BS, Bellad RM, Mahantshetti NS et al (2013) Biofortification of pearl millet with iron and zinc in a randomized controlled trial increases absorption of these minerals above physiologic requirements in young children. J Nutr 143:1489-1493. https://doi.org/10.3945/jn.113.176677

Korshunova YO, Eide D, Clark WG et al (1999) TheIRT1proteinfrom Arabidopsis thaliana is a metal transporter with a broad substrate range. Plant Mol Biol 40:37-44. https://doi.org/10.1023/A: 1026438615520
Kramer CV, Allen S (2015) Malnutrition in developing countries. Paediatr Child Health 25:422-427. https://doi.org/10.1016/j. paed.2015.04.002

Krishna TPA, Maharajan T, Roch GV et al (2020) Structure, function, regulation and phylogenetic relationship of ZIP family transporters of plants. Front Plant Sci 11:662. https://doi.org/10.3389/ fpls.2020.00662

Kubesova M, Moravcova L, Suda J et al (2010) Naturalized plants have smaller genomes than their non-invading relatives: a flow cytometric analysis of the Czech alien flora. Preslia-Praha 82:81-96

Kulkarni LR, Naik RK (2000) Nutritive value, protein quality and organoleptic quality of kodo millet (Paspalum scrobiculatum). Karnataka J Agric Sci 13:125-129

Kumar A, Metwal M, Kaur S et al (2016) Nutraceutical value of finger millet [Eleusine coracana (L.) Gaertn.], and their improvement using omics approaches. Front Plant Sci 7:934. https://doi.org/10.3389/fpls.2016.00934

Kumar A, Tomer V, Kaur A et al (2018) Millets: a solution to agrarian and nutritional challenges. Agric Food Secur 7:31. https://doi.org/10.1186/s40066-018-0183-3

Larson G, Piperno DR, Allaby RG et al (2014) Current perspectives and the future of domestication studies. Proc Natl Acad Sci 111:6139-6146. https://doi.org/10.1073/pnas.1323964111

Li HF, McGrath SP, Zhao FJ (2008) Selenium uptake, translocation and speciation in wheat supplied with selenate or selenite. New Phytol 178:92-102. https://doi.org/10.1111/j.1469-8137.2007. 02343.x

Liang K, Liang S, Zhu H (2020) Comparative proteomics analysis of the effect of selenium treatment on the quality of foxtail millet. LWT 131:109691. https://doi.org/10.1016/j.lwt.2020.109691

Mackowiak CL, Grossl PR (1999) Iodate and iodide effects on iodine uptake and partitioning in rice (Oryza sativa L.) grown in solution culture. Plant Soil 212:135-143. https://doi.org/10. 1023/a:1004666607330

Mahendrakar MD, Parveda M, Kishor PBK et al (2020) Discovery and validation of candidate genes for grain iron and zinc metabolism in pearl millet [Pennisetum glaucum (L.) R. Br.]. Sci Rep 10:16562. https://doi.org/10.1038/s41598-020-73241-7

Malik S (2015) Pearl millet-nutritional value and medicinal uses! Int J Adv Res Innov Ideas Educ 1:414-418

Manisseri C, Gudipati M (2012) Prebiotic activity of purified xylobiose obtained from ragi (Eleusine coracana, Indaf-15) Bran. Ind J Med Microbiol 52:251-257. https://doi.org/10.1007/ s12088-011-0176-4

Manwaring HR, Bligh HFJ, Yadav R (2016) The challenges and opportunities associated with biofortification of pearl millet (Pennisetum glaucum) with elevated levels of grain iron and zinc. Front Plant Sci 7:1944. https://doi.org/10.3389/fpls.2016. 01944

Marschner H, Rimmington G (1988) Mineral nutrition of higher plants. Plant Cell Environ 11:147-148. https://doi.org/10.1111/ 1365-3040.ep11604921

Martel E, De Nay D, Siljak-Yakovlev S et al (1997) Genome size variation of basic chromosome number in pearl millet and fourteen related Pennisetum species. J Hered 88:139-143. https://doi.org/10.1093/oxfordjournals.jhered.a023072

Mbithi-Mwikya S, Ooghe W, Van Camp J et al (2000) Amino acid profile after sprouting, autoclaving and lactic acid fermentation of finger millet (Eleusine coracana) and kidney beans (Phaseolus vulgaris L.). J Agric Food Chem 48:3081-3085. https://doi. org/10.1021/jf0002140

Mikulikova D, Cicova I, Anatalikova G et al (2005) Grains of nontraditional crops as sources of retrograded resistant starch. Czech J Genet Plant Breed 41:96-104. https://doi.org/10.17221/ 3667-CJGPB 
Mishra M, Shukla YN, Kumar S (2000) Chemistry and biological activity of Paspalum scrobiculatum: a review. J Med Arom Plant Sci 22:288-292

Mohamed TIC, Zhu K, Issoufou A et al (2009) Functionality, in vitro digestibility and physicochemical properties of two varieties of defatted foxtail millet protein concentrates. Int $\mathrm{J}$ Mol Sci 10:522-438. https://doi.org/10.3390/ijms 10125224

Morrissey J, Guerinot ML (2009) Iron uptake and transport in plants: the good, the bad, and the ionome. Chem Rev 109:4553-4567. https://doi.org/10.1021/cr900112r

Murdock GP (1959) Africa: its people and their cultural history. McGraw-Hill, New York

Nadeem F, Ahmad Z, Wang R et al (2018) Foxtail millet [Setariaitalica (L.) Beauv.] grown under low nitrogen shows a smaller root system, enhanced biomass accumulation, and nitrate transporter expression. Front Plant Sci 9:205. https://doi.org/10. 3389/fpls.2018.00205

Numan M, Khan AL, Asaf S et al (2021) From traditional breeding to genome editing for boosting productivity of the ancient grain tef [Eragrostis tef (Zucc.) Trotter]. Plants 10:628. https://doi.org/10. 3390/plants10040628

Oei L, Zillikens MC, Ehghan A et al (2013) High bone mineral density and fracture risk in type 2 diabetes as skeletal complications of inadequate glucose control: the Rotterdam study. Diabetes Care 36:1619-1628. https://doi.org/10.2337/ dc12-1188

Olsen LL, Palmgren MG (2014) Many rivers to cross: the journey of zinc from soil to seed. Front Plant Sci 5:30. https://doi.org/10. 3389/fpls.2014.00030

Parikh SJ, Yanovski JA (2003) Calcium intake and adiposity. Am J Clin Nutr 77:281-287. https://doi.org/10.1093/ajcn/77.2.281

Passi JS, Jain A (2014) Millets: the nutrient rich counterparts of wheat and rice. Press Information Bureau, Government of India. http:// pib.nic.in/newsite/mbErel.asp

Paul S, Datta SK, Datta K (2015) miRNA regulation of nutrient homeostasis in plants. Front Plant Sci 6:232. https://doi.org/10. 3389/fpls.2015.00232

Pujar M, Govindaraj M, Gangaprasad S et al (2020) Genetic variation and diversity for grain iron, zinc, protein and agronomic traits in advanced breeding lines of pearl millet [Pennisetum glaucum (L.) R. Br.] for biofortification breeding. Genet Resour Crop Evol 67:2009-2022. https://doi.org/10.1007/s10722-020-00956$\mathrm{x}$

Puranik S, Kam J, Sahu PP et al (2017) Harnessing finger millet to combat calcium deficiency in humans: challenges and prospects. Front Plant Sci 8:1311. https://doi.org/10.3389/fpls.2017.01311

Ramakrishnan M, Ceasar SA, Duraipandiyan V et al (2015) Using molecular markers to assess the genetic diversity and population structure of finger millet (Eleusine coracana (L.) Gaertn.) from various geographical regions. Genet Resour Crop Evol 63:361-376. https://doi.org/10.1007/s10722-015-0255-1

Rao KEP, de Wet JMJ, Brink DK et al (1987) Intraspecific variation and systematics of cultivated Setaria italica, foxtail millet (Poaceae). Econ Bot 41:108-116. https://doi.org/10.1007/ BF02859358

Rao DB, Bhaskarachary K, Christina AGD et al (2017) Nutritional and health benefits of millets. In: Rao DB, Malleshi NG, Annor GA, Patil JV (eds) Millets value chain for nutritional security: a replicable success model from India. CABI, New Delhi, pp 24-48

Renganathan VG, Vanniarajan C, Karthikeyan A et al (2020) Barnyard millet for food and nutritional security: current status and future research direction. Front Genet 11:500. https://doi. org/10.3389/fgene. 2020.00500

Roch GV, Maharajan T, Krishna TPA et al (2020) Expression of PHT1 family transporter genes contributes for low phosphate stress tolerance in foxtail millet (Setariaitalica) genotypes. Planta 252:98. https://doi.org/10.1007/s00425-020-03503-1

Sakamma S, Umesh KB, Girish MR et al (2018) Finger millet (Eleusine coracana (L.) Gaertn.) production system: status, potential, constraints and implications for improving small farmer's welfare. J Agric Sci 10:162-179. https://doi.org/10. 5539/jas.v10n1p162

Saleh ASM, Zhang Q, Chen J, Shen Q (2013) Millet grains: nutritional quality, processing, and potential health benefits. Compr Rev Food Sci Food Saf 12:281-295. https://doi.org/10. 1111/1541-4337.12012

Sanusi SN, Sulaiman SA, Hadiza HK (2019) Comparative of proximate and mineral composition of commercially-available millet types in Katsina metropolis, Nigeria. World J Food Sci Technol 3:14-19. https://doi.org/10.11648/j.wjfst.20190301.13

Schiavon M, Nardi S, Dalla Vecchia F et al (2020) Selenium biofortification in the 21st century: status and challenges for healthy human nutrition. Plant Soil 453:245-270. https://doi.org/ 10.1007/s11104-020-04635-9

Shankaramurthy KN, Somannavar MS (2019) Moisture, carbohydrate, protein, fat, calcium and zinc content in finger, foxtail, pearl and proso millets. Ind $\mathbf{J}$ Health Sci Biomed Res 12:228-232. https://doi.org/10.4103/kleuhsj.Kleuhs_32_19

Sharma N, Niranjan K (2018) Foxtail millet: properties, processing, health benefits, and uses. Food Rev Int 34:329-369. https://doi. org/10.1080/87559129.2017.1290103

Small E (2015) Teff and fonio-Africa's sustainable cereals. Biodiversity 16:37-41. https://doi.org/10.1080/14888386.2014. 997290

Srilekha K, Kamalaja T, Maheswari KU et al (2019) Nutritional composition of little millet flour. Int Res J Pure Appl Chem 31:1-4. https://doi.org/10.9734/irjpac/2019/v20i430140

Tadele Z, Assefa K (2012) Increasing food production in Africa by boosting the productivity of understudied crops. Agronomy 2:240-283. https://doi.org/10.3390/agronomy2040240

Takahashi H, Saito K (2008) Molecular biology and functional genomics for identification of regulatory networks of plant sulfate uptake and assimilatory metabolism. In: Sulfur metabolism in phototrophic organisms. Springer, Berlin/Heidelberg, pp 149-159

Tharifkhan SA, Perumal AB, Elumalai A et al (2021) Improvement of nutrient bioavailability in millets: emphasis on the application of enzymes. J Sci Food Agric. https://doi.org/10.1002/jsfa.11228

UNICEF/WHO/The World Bank Group joint child malnutrition estimates: levels and trends in child malnutrition: key findings of the 2021 edition

Upadhyaya HD, Dwivedi SL, Singh SK et al (2014) Forming core collections in barnyard, kodo, and little millets using morphoagronomic descriptors. Crop Sci 54:2673-2682. https://doi.org/ 10.2135/cropsci2014.03.0221

USDA Food Composition Databases (2017) Food data central. USDA, Washington

VanBuren R, Wai CM, Wang X et al (2020) Exceptional subgenome stability and functional divergence in the allotetraploid Ethiopian cereal teff. Nat Commun 11:884. https://doi.org/10.1038/ s41467-020-14724-Z

Varshney RK, Shi C, Thudi M et al (2017) Pearl millet genome sequence provides a resource to improve agronomic traits in arid environments. Nat Biotechnol 35:969-976. https://doi.org/10. 1038/nbt.3943

Vetriventhan M, Azevedo VCR, Upadhyaya HD et al (2020) Genetic and genomic resources, and breeding for accelerating improvement of small millets: current status and future interventions. Nucleus 63:217-239. https://doi.org/10.1007/s13237-02000322-3 
Vijayakumari J, Mushtari Begum J, Begum S et al (2003) Sensory attributes of ethnic foods from finger millet (Eleusine coracana). In: Proceeding of the national seminar on processing and utilization of millet for nutrition security: recent trends in millet processing and utilization. CCSHAV, Hisar, pp 7-12

Vodouhe RS, Dako GEA, Dansi A (2007) Fonio: a treasure for West Africa. In: Plant genetic resources and food security in West and Central Africa. Ibadan, Nigeria, pp 219-222

Wang X, Chen S, Ma X et al (2021) Genome sequence and genetic diversity analysis of an under-domesticated orphan crop, white fonio (Digitaria exilis). GigaScience 10:giab013. https://doi.org/ 10.1093/gigascience/giab013

Wanous MK (1990) Origin, taxonomy and ploidy of the millets and minor cereals. Plant Var Seeds 3:99-112

Watanabe M (1999) Antioxidative phenolic compounds from Japanese barnyard millet (Echinochloa utilis) grains. J Agric Food Chem 47:4500-4505. https://doi.org/10.1021/jf990498s

Webb P, Stordalen GA, Singh S et al (2018) Hunger and malnutrition in the 21st century. BMJ 361:k2238. https://doi.org/10.1136/bmj. k2238

Welch RM, Graham RD (2004) Breeding for micronutrients in staple food crops from a human nutrition perspective. J Exp Bot 55:353-364. https://doi.org/10.1093/jxb/erh064

Yadav OP, Gupta SK, Govindaraj M et al (2021) Genetic gains in pearl millet in India: insights into historic breeding strategies and future perspective. Front Plant Sci 12:645038. https://doi.org/10. 3389/fpls.2021.64503

Yamunarani R, Govind G, Ramegowda V et al (2016) Genetic diversity for grain $\mathrm{Zn}$ concentration in finger millet genotypes: potential for improving human Zn nutrition. Crop J 4:229-234. https://doi.org/10.1016/j.cj.2015.12.001

Yang Q, Zhang W, Li J et al (2019) Physicochemical properties of starches in proso (non-waxy and waxy) and foxtail millets (nonwaxy and waxy). Molecules 24:1743. https://doi.org/10.3390/ molecules24091743

Zhao FJ, McGrath SP (2009) Biofortification and phytoremediation. Curr Opin Plant Biol 12:373-380. https://doi.org/10.1016/j.pbi. 2009.04.005

Zhu F (2020) Fonio grains: physicochemical properties, nutritional potential and food applications. Compr Rev Food Sci Food Saf 19:3365-3389. https://doi.org/10.1111/1541-4337.12608

Zou C, Li L, Miki D et al (2019) The genome of broomcorn millet. Nat Commun 10:436. https://doi.org/10.1038/s41467-01908409-5

Publisher's Note Springer Nature remains neutral with regard to jurisdictional claims in published maps and institutional affiliations. 